\title{
Effectiveness of low frequency harvesting systems in rubber smallholder sector of Eastern province (IL2) of Sri Lanka
}

\author{
R G N Lakshman*, K V V S Kudaligama*, V H L Rodrigo*, A Nugawela**, \\ A P Attanayake*, M K P Perera* and P D T L Madushani* \\ * Rubber Research Institute of Sri Lanka, Dartonfield, Agalawatta, Sri Lanka \\ ** Department of Plantation Management, Faculty of Agriculture \& Plantation Management, \\ Wayamba University of Sri Lanka, Makandura, Gonawila
}

\begin{abstract}
With no experience on Low Frequency harvesting (LFH) systems in the drier climates, tapping half of the tree circumference once in four days $(S / 2 d 4)$ instead of traditionally doing once in two days ( $S / 2$ d2) was tested in rubber smallholdings established in Eastern Province of Sri Lanka. Yields given by $S / 2$ d4 was slightly higher than that of $S / 2 d 2$ and also, found financially more profitable, particularly under hired labour conditions. Quality of raw rubber produced was also not affected by LFH. Seasonal distribution of rubber yields showed that $S / 2$ d4 system outperforms in rainy period whilst yields of $S / 2$ d2 was higher in dry months. Also, demand for labour was higher in the rainy period due to the establishment of seasonal crops. Therefore, it is suggested to apply S/2 d4 only during wet periods (September to March in the following year) and $S / 2 d 2$ in dry months (April to August). Reasons for the above responses are also discussed.
\end{abstract}

Keywords: Bark consumption, cost of production, latex harvesting, low frequency harvesting

\section{Introduction}

Rubber industry play a vital role in Sri Lankan economy and it is generating income by raw rubber and rubber product. The amount of foreign exchange by exporting raw rubber and end products in year 2014 was about USD million 940 (Anon, 2014). Rubber plantations in Sri Lanka lie in the Wet zone (WZ) of the country and no sufficient lands for further cultivation of rubber in traditional growing areas, based on the research findings of the rubber Research Institute of Sri Lanka, the Ministry of Plantation Industries had decided to expand rubber in to the Intermediate and Dry zone areas in Eastern and Northern provinces. In addition to the rubber production, Government of Sri Lanka (GoSL) seeks multiple benefits in the expansion process, i.e. improved environment with forest cover and enhanced rural livelihood. The Ministry of Plantation 
R G N Lakshman et al.

Industry targeted to cultivate $10,000 \mathrm{ha}$ in Ampara District and 1,400ha had been cultivated by the end of 2013 (Anon, 2014).

Traditionally, rubber tree is tapped with $\mathrm{S} / 2$ d2 system (tapping a half of the circumference of the trunk at the frequency of once in two days). Hence, a harvester could tap only two blocks of trees (tapping blocks) making harvesting a labour intensive activity in rubber cultivation. Though local and international attempts have been tried to mechanize tapping in order to reduce the cost on tapping and to remove the skill factor, a commercially practical device has not yet been developed. Hence, reduction of harvesting frequency to improve the efficiency in the usage of skilled harvesters has become an internationally accepted management system in rubber cultivation. Low frequency harvesting (LFH) allows each harvester to be allocated a higher number of tapping blocks resulting in reduced harvester requirement when compared with the traditional $\mathrm{S} / 2 \mathrm{~d} 2$ tapping system. In order to compensate the yield loss due to less number of tapping days per tree, ethephon is used as the yield stimulant to increase the yield per tree per tapping. This results in enhanced daily intake per harvester and therefore, their wages can be increased. Furthermore, overall increase in harvesters' productivity results in reduction of cost of production (COP). Less bark consumption in LFH results in increased economic life of the tree providing an additional benefit to the growers.

Experiments done in India (Karunaichamy et al., 2001; Vijayakumar et al., 2002), Malaysia (Ahmad et al., 1991; Kewi and Sivakumaran, 1994) and China (Xuehua et al., 2004) were in favour of LFH systems and with that, tapping a tree once in four, five and six days was recommended. Response of LFH systems depend on the climatic conditions (Vijayakumar et al., 2002). First recommendation on LFH i.e. half spiral tapping once in three days with the application of $2.5 \%$ ethephon, $4-5$ round per year was issued to Sri Lankan growers in 1994 and this system would bring down the harvester requirement by 1/3 (Nugawela, 2001; Nugawela et al., 2000). Recently, Rubber Research Institute of Sri Lanka has recommended $\mathrm{S} / 2$ d4 system with application of 12 rounds of $3.3 \%$ ethephon at monthly intervals (Rodrigo et al., 2011). This system reduced the intensity of harvesting by $50 \%$ and increase the harvester productivity by $100 \%$ (Kudaligama et al., 2015). Though this system has been successful in Wet zone of the country, its effectiveness under the suboptimal climatic conditions in Intermediate zone has not been studied systematically. Therefore, this study was aimed to investigate the effectiveness of $\mathrm{S} / 2 \mathrm{~d} 4$ system under dry climatic condition in Eastern province and benefits to the rural rubber farmers in the area. 


\section{Materials and Methods}

Three mature rubber smallholdings replanted with RRIC 121 genotype in Padiyathalawa of Ampara district which lies in IL 2 Agro-ecological zone was selected for testing the effectiveness of $\mathrm{S} / 2 \mathrm{~d} 3$ (tapping half spiral of the tree once in three days frequency) and $\mathrm{S} / 2$ d4 (tapping half spiral of the tree once in four days frequency) systems under prevailing dry climatic conditions in the Intermediate zone. Trees were planted in 2003 and tapping was started in 2011. Approximate number of trees in each field were between 200- 250 and about 60 - 75 trees was selected to harvested with $S / 2 d 3$ and $S / 2 d 4$ systems with the application of $2.5 \%$ ethephon quarterly (4 rounds per year) and 3.3\% ethephon monthly (10 rounds per year), respectively as the yield stimulant to compensate the yield loss due to lowering the tapping frequency. June July period stimulation was suspended due to prevailing dry condition in the area.

Rest of the trees in each field were harvested with traditional once in two days $(\mathrm{S} / 2 \mathrm{~d} 2)$ harvesting system without stimulation for comparison. Experiment began in 2013. In each tapping day latex volume and dry weight of rubber was recorded. In every six months girth of trees, bark thickness, bark consumption and incidence of tapping panel dryness were also assessed. Ribbed smoked sheets (RSS) processed from the latex collected under $\mathrm{S} / 2 \mathrm{~d} 2$, $\mathrm{S} / 2 \mathrm{~d} 3$ and $\mathrm{S} / 2 \mathrm{~d} 4$ harvesting systems were assessed for raw rubber properties i.e. initial plasticity (Po), plasticity retention index (PRI), Mooney viscosity $\left(\mathrm{V}_{R}\right)$, colour, nitrogen and ash content using the standard test methods stipulated by the International Standard Organization (Anon, 1984).

Local weather condition was monitored with a simple metrological station established at Komana Maha Vidyalaya in the area. It comprised a rain gauge, maximum and minimum thermometers, wet and dry bulb thermometers and a pan evaporator.

From daily records on latex yields and the actual number of tapping days, mean values for yield per tree per year (YPT), yield per hectare per annum (YPH) and daily intake per harvester (IPH) were derived for each tapping system. Similarly, growth data and at tree level were processed into mean values in each treatment of each plot. Three harvesting systems tested were statistically analysed using the statistical package the SAS system 9.2.

Financial viability of $S / 2 d 4$ harvesting system was assessed at commercial level with the knowledge on both cost and benefit components for a given period of one year. Tapping cost was based on the current daily wage of workers (LKR 800/=) in the area and ethephon application cost (chemical cost, LKR 5,425/= per 5 litre plus the labour cost of LKR 400/= per tapping block per application). Labour for weed control, cost of chemicals and maintenance of latex collecting utensils were the other costs taken for calculating the cost of production. 
R G N Lakshman et al.

Prevailing prices for ribbed smoked sheets (RSS) and scrap rubber i.e. LKR 200/= and LKR 80/=, respectively were taken for the financial analysis.

\section{Results}

Rainy season to Padiyathalawa area started in mid October and lasted till February in the following year. Highest rainfall was received during December - January period and few showers were also available till April. Drought period started from end of April and came to peak during June. Annual rainfall and number of rainy days were $900.1 \mathrm{~mm}$ and 51 , respectively. However, $70 \%$ of the rainfall was received during November - January period and average relative humidity $(\% \mathrm{RH})$ during these
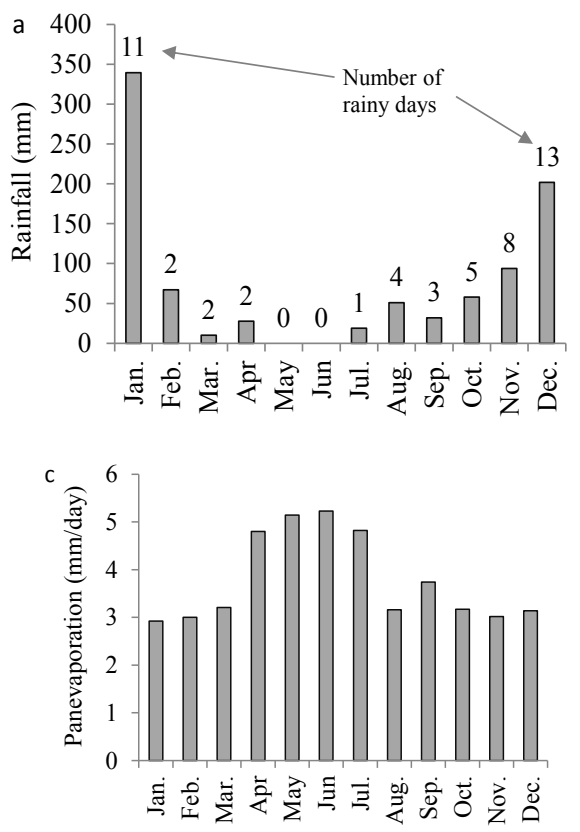

wet months were above $90 \%$ and average falls to about $78 \%$ during dry months (Fig. 1a and 1b). During initial three months of the year panevaporation was about $3.00 \mathrm{~mm} /$ day and this was increased to about $5 \mathrm{~mm} /$ day during April - July period and thereafter gradually decreased with the receiving rainfall (Fig. 1c). Average minimum and maximum temperature were $24.13^{\circ} \mathrm{C}$ and $34.90^{\circ} \mathrm{C}$, respectively in the area. During January - May, observed minimum and maximum temperatures were below the average and thereafter these increased giving the highest during June - September period. With the beginning of monsoon towards the end of year both values gradually decreased (Fig. 1d).
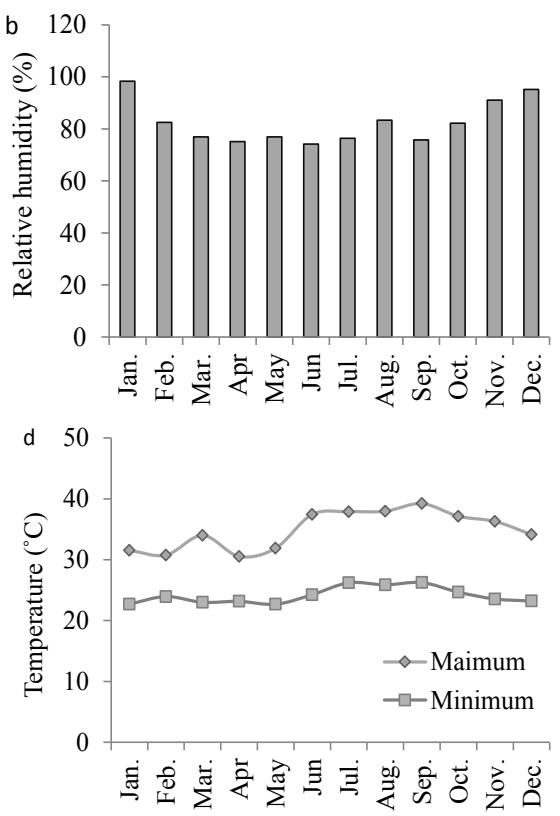

Fig. 1. Environmental conditions in Padiyathalawa area 
Harvesting rubber with $\mathrm{S} / 2 \mathrm{~d} 4$ system in Eastern province

Table 1. Average yield parameters of $S / 2 d 2$ and $S / 2$ d4 harvesting systems (Yield per hectare has been derived at the standard planting density of 400 tree/ha)

\begin{tabular}{lrrrrr}
\hline $\begin{array}{l}\text { Tapping } \\
\text { system }\end{array}$ & $\begin{array}{r}\text { Actual } \\
\text { tapping days } \\
\text { (per tree) }\end{array}$ & $\begin{array}{r}\text { Dry rubber } \\
\text { content }(\%)\end{array}$ & $\begin{array}{r}\text { Yield per } \\
\text { tree per } \\
\text { tapping }(\mathbf{g})\end{array}$ & $\begin{array}{r}\text { Yield per } \\
\text { tree per } \\
\text { year }(\mathbf{k g})\end{array}$ & $\begin{array}{r}\text { Yield per } \\
\text { hectare per } \\
\text { year (kg) }\end{array}$ \\
\hline $\mathrm{S} / 2 \mathrm{~d} 2$ & 128 & $38.17 \pm 0.45$ & $21.05 \pm 1.03$ & 2.69 & 1078 \\
$\mathrm{~S} / 2 \mathrm{~d} 4$ & 69 & $37.99 \pm 0.45$ & $44.75 \pm 2.86$ & 3.09 & 1235 \\
\hline
\end{tabular}

In all three fields monitored, dry rubber content of latex (\%DRC) of $\mathrm{S} / 2 \mathrm{~d} 4$ system had not shown any significant difference from that of $\mathrm{S} / 2 \mathrm{~d} 2$ system and values did not fall below 35\% in both harvesting systems throughout the period (Table 1).

Though not statistically significant, average annual yield received by $\mathrm{S} / 2 \mathrm{~d} 4$ was higher than that of $\mathrm{S} / 2 \mathrm{~d} 2$ system. Similarly, average yield received from a tree tapped under $\mathrm{S} / 2 \mathrm{~d} 4$ system was greater than that of $\mathrm{S} / 2 \mathrm{~d} 2$ system (Table 1).

When compared to the expected level, bark consumption per tapping was slightly higher in $\mathrm{S} / 2$ d4 system. However, annual bark consumption was $22.30 \mathrm{~cm}$ and $12.20 \mathrm{~cm}$ in $\mathrm{S} / 2 \mathrm{~d} 2$ and $\mathrm{S} / 2$ d4 systems, respectively. Therefore, expected years for harvesting in base panels in $\mathrm{S} / 2 \mathrm{~d} 4$ system showed $77 \%$ increase over that of $S / 2 \mathrm{~d} 2$.

Trees affected with tapping panel dryness (TPD) were below $1 \%$ in both harvesting systems and the incidence of TPD was not significantly different among $\mathrm{S} / 2 \mathrm{~d} 2$ and $\mathrm{S} / 2 \mathrm{~d} 4$ harvesting systems. Average girth and bark thickness of trees in the fields monitored were $52.77 \mathrm{~cm}$ and $5.92 \mathrm{~cm}$, respectively. Though not significant, annual rate of increase of girth and bark thickness of trees harvested with $\mathrm{S} / 2 \mathrm{~d} 4$ system were lower than that of $S / 2 d 2$ system.

Initial plasticity $(\mathrm{Po})$, plasticity retention index (PRI), Mooney viscosity $\left(\mathrm{V}_{R}\right)$, ash $\%$, nitrogen $\%$ and Lovibond colour did not show any significant variation between two harvesting systems (Table 2).

Table 2. Variation in raw rubber properties of ribbed smoked sheets (RSS) produced under $S / 2$ d2 and $S / 2$ d4 systems

\begin{tabular}{llllll}
\hline $\begin{array}{l}\text { Harvesting } \\
\text { systems }\end{array}$ & $\begin{array}{l}\text { Po (Wallace } \\
\text { units) }\end{array}$ & PRI & $\begin{array}{l}\mathbf{V}_{\mathbf{R}}(\mathbf{M L} \\
\mathbf{1 + 4} \boldsymbol{0} \mathbf{1 0 0} \mathbf{0})\end{array}$ & $\begin{array}{l}\text { Nitrogen } \\
(\% \mathbf{\%} / \mathbf{w})\end{array}$ & Ash (\%w/w) \\
\hline S/2 d2 & $35.35 \pm 0.96$ & $86.26 \pm 1.96$ & $62.26 \pm 1.59$ & $0.28 \pm 0.01$ & $0.26 \pm 0.012$ \\
S/2 d4 & $34.81 \pm 1.03$ & $84.65 \pm 1.63$ & $59.87 \pm 1.60$ & $0.29 \pm 0.01$ & $0.26 \pm 0.013$ \\
\hline
\end{tabular}


During wet months average yield and income was significantly higher when trees were tapped with $\mathrm{S} / 2 \mathrm{~d} 4$ system by farmers. However, the difference in yield and income in $S / 2 d 2$ and $S / 2 d 4$ systems were not significant during dry months. At any time harvesting trees with $\mathrm{S} / 2 \mathrm{~d} 2$ system by hired labour gave the least financial benefit. In some months financial benefit is higher in $\mathrm{S} / 2$ d4 system even with use of hired labour than use of own labour in $\mathrm{S} / 2 \mathrm{~d} 2$ harvesting (Fig. $2 \& 3$ ).
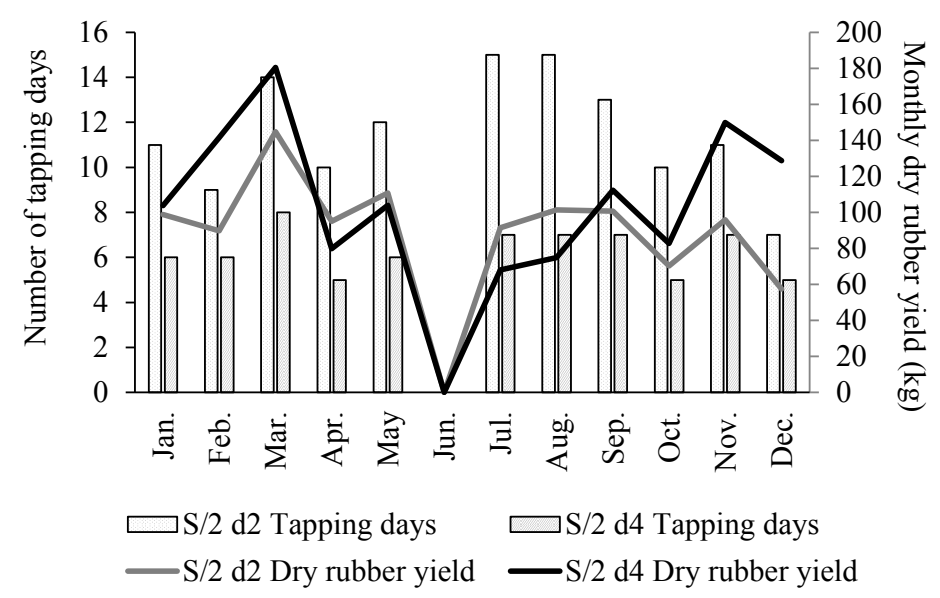

Fig. 2. Seasonal variation in tapping days and expected dry rubber yield to be received from a one hectare of rubber land

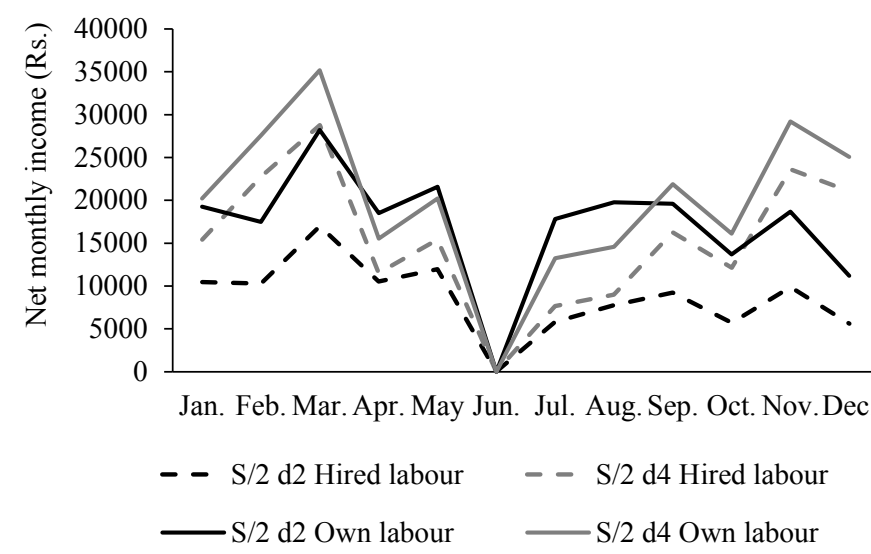

Fig. 3. Net monthly income of one hectare of rubber land managed with hired labour and own labour condition 
Other than the tapping, costs involved for cost of production (COP) were cost for weed control, chemicals and maintenance of tapping and latex collecting utensils in the field. Under hired and own labour condition COP other than tapping cost was LKR 5.50 and LKR 1.50, respectively per production of one $\mathrm{kg}$ of dry rubber. Profit from 1 ha of rubber land tapped with hired labour using $\mathrm{S} / 2 \mathrm{~d} 2$ system was LKR $40,102 /=$ per year and with the adoption $\mathrm{S} / 2 \mathrm{~d} 4$ system net profit per ha of rubber land further increased by LKR $65,738 /=$. If the trees were tapped with own labour, the profitability from 1 ha of rubber land tapped with $\mathrm{S} / 2 \mathrm{~d} 2$ and $\mathrm{S} / 2 \mathrm{~d} 4$ system were LKR $189,964 /=$ and LKR 193,627/=, per year respectively.

\section{Discussion}

The success of expanding process of rubber cultivation to drier regions depends on the latex yield given and how effectively it can be harvested in the socio-economic environment in the peasant community. The present study has shown not only the applicability of a newly developed low frequency harvesting system (i.e. $\mathrm{S} / 2 \mathrm{~d} 4$ ) but also how best the usually practiced $\mathrm{S} / 2 \mathrm{~d} 2$ fits into such environment. With no detailed studies carried out on yield pattern of rubber in this climatic conditions before, the present study is unique in providing necessary information to apply the suitable harvesting systems to meet the climatic and social conditions in the Intermediate
Zone (IZ) of Sri Lanka. Rainfall pattern in the experimental area is rather unimodal with very distinct dry period; hence it features drier conditions than other IZ areas (having bimodal rainfall) where rubber is grown (e.g. Monaragala). Therefore, findings of this study will also be applicable to Dry Zone areas where newly planted rubber fields are yet to be harvested.

The yield given by both systems of harvesting exceeded $1000 \mathrm{~kg} / \mathrm{ha} /$ year. Although this level might be below the general expectation (i.e. 1500 $\mathrm{kg} / \mathrm{ha} /$ year), it depicts national average yield which is principally based on the yields in traditional wet areas of the country. Rubber trees are still in the early stage of harvesting and yields should increase further with the growth of trees. Also, number of tapping days recorded in both harvesting systems was much below the value to be and that is also a major contributory factor for low yields. Nevertheless, total yield given by $\mathrm{S} / 2$ d4 low frequency harvesting (LFH) system was slightly superior to that of usually practised $S / 2 d 2$, hence its worthiness would be out of question. This is further confirmed by the financial analysis. Latex harvesting is the most costly operation in rubber fields and therefore with comparatively less labour requirement in $S / 2 d 4$, the gap in profitability between two tapping systems increases under the condition of hired labour.

The reason for comparatively poor performance of $\mathrm{S} / 2 \mathrm{~d} 4$ in dry months would be that more water is to be taken 
R G N Lakshman et al.

out as latex on each tapping day of this system and this is affected by the poor water status in the plant (N.B. ca. $90 \%$ of latex is water). Nevertheless, latex quality in terms of quality parameters tested in raw rubber produced (RSS) was not affected by LFH. Another advantage of LFH shown in the study was the potential of keeping the rubber tree longer with reduced bark consumption. In drier climates, early establishment of rubber plants is a challenge and therefore, once established, tapping is to be undertaken carefully to keep trees longer. Unlike wet region, incidence of root diseases does not influence to reduce the tree density to a greater extent in drier climates. Therefore, this advantage can be explored with $\mathrm{S} / 2 \mathrm{~d} 4 \mathrm{LFH}$ system to meet the need of extended tree lifespan in drier climates.

Farmers in traditional wet region do not usually change the harvesting frequency adopted due to the convenience in hiring workers for tapping. However, this may not be an issue in the social conditions in drier regions where farmers use own or shared labour in onfarm operations. They need to manage themselves rubber tapping as well as other farm operations during peak labour demanding periods associated with the establishment of other crops (seasonal crops). Therefore, farmers may forgo tapping on some days and this effect is more prominent in high frequency systems as shown in the present study (N.B. Reduction in tapping days from the expected level was higher in $\mathrm{S} / 2 \mathrm{~d} 2$ system which requires more labour inputs than in $\mathrm{S} 2$ d4 LFH). On other hand, the yield performance of $\mathrm{S} / 2 \mathrm{~d} 4$ was better during wet periods whilst $\mathrm{S} / 2 \mathrm{~d} 2$ performed better in dry periods. During wet periods, farmers need to be engaged in other farm operations required for seasonal crops. Therefore, the best would be to have a combination of harvesting systems in which all issues are addressed. Considering the temporal (seasonal) advantages of different harvesting systems, $\mathrm{S} / 2 \mathrm{~d} 4 \mathrm{can}$ be practiced only during wet periods (September to March in the following year) whilst engaging in farm operations for other crops and then $S / 2 d 2$ is to be practiced during dry months (April to August). In this way, higher monthly and then annual yields could be obtained than what were recorded in the present study. Also, number of ethephon stimulations are limited to the months of $\mathrm{S} / 2 \mathrm{~d} 4$ and thereby, the cost involved can be minimized.

\section{Conclusion}

Newly developed S/2 d4 low frequency system could be successfully be adapted in combination with $\mathrm{S} / 2$ d2 for harvesting rubber in drier areas. Considering the seasonal advantage of different harvesting systems, $\mathrm{S} / 2 \mathrm{~d} 4$ can be practiced during wet period (September - March in the following year) limiting the use of $S / 2 d 2$ to dry months (April - August). 


\section{Acknowledgement}

National Science Foundation of Sri Lanka is gratefully acknowledged for the financial assistance given under grant No: RG/ 2011/AG/10.

\section{Referances}

Ahmad, Z M T, Kewi, C and Hashim, I (1991). Low intensity tapping systems and early use of CUT. Proceedings of the Rubber Growers' Conference. Kuala Lumpur, Malaysia pp. 189-211.

Anon (1984). ISO standards Hand book 22, Volume 1 and 2. International Standard Organization.

Anon (2014). Annual Report of Central Bank of Sri Lanka.

Karunaichamy, K, Vijayakumar, K R, Thomas, K U, Rajagopal, R and Anil Kumar, D. (2001). Response of rubber trees (Hevea brasiliensis Muell, Arg., clone RRII 105) to low frequency tapping (LFT) systems. Indian Journal of Natural Rubber Research 14 (2), 79-87.

Kewi, C and Sivakumaran, S (1994). Performance of Low-Frequency tapping systems. Proceedings of the Workshop of the Exploitation Technologies to Address Current Labour Problems in the Rubber Industry. Kuala Lumpur, Malaysia. pp. 47-67.

Kudaligama, K V V S, Rodrigo, V H L and R P S Randunu (2015). Commercial application of $S / 2 d 4$ harvesting system to address current issues in rubber plantations in Sri Lanka. Proceedings of the International Rubber Conference, Ho Chi Minh City, Viet Nam, pp. 386-396.
Nugawela, A (2001). Exploitation for economic yields. In: Handbook of Rubber, Vol.1 Agronomy. pp. 176-190 (Eds. L M K Tillekeratne and A Nugawela) Rubber Research Institute of Sri Lanka, Agalawatta, Sri Lanka.

Nugawela, A, Peries, M R C, Wijesekera, S and Samarasekera, R K (2000). Evaluation of $d / 3$ tapping with stimulation to alleviate problems related to $\mathrm{d} / 2$ tapping of Hevea. Journal of the Rubber Research Institute of Sri Lanka 83, 49-61.

Rodrigo, V H L, Kudaligama, K V V S, Fernando, K M E P and Yapa, P A J (2011). Harvesting the rubber tree once in four days; a solution to the current issues in the rubber industry in Sri Lanka. Journal of Rubber Research Institute of Sri Lanka 91, 15-35.

Vijayakumar K R, Thomas K U, and Rajagopal R, and Karunaichamy, K (2002). Advances in exploitation research of Hevea in India. Proceedings of the Rubber Planters' Conference, Kottyam, India, pp. 155-162

Xuehua, L U O, Yunqing, L I U, Xiujuan, C $\mathrm{A}$ I, Juqun, $\mathrm{W} \mathrm{U}$ and Bixia, $\mathrm{Z} \mathrm{H} \mathrm{O} \mathrm{U}$ (2004). Effect of different tapping systems on the mineral nutrient of latex total solids of RRIM 600 tree. Proceedings of the International Rubber Research and Development Board Conference, Kunming, China. pp. 8.

Address for correspondence: Dr (Mrs) K V V S Kudaligama, Senior Research Officer, Biochemistry \& Physiology Dept., Rubber Research Institute of Sri Lanka, Dartonfield, Agalawatta, Sri Lanka.

e-mail:vskudaligama@yahoo.com 